\title{
Effect of Row-spacing and Weed Management Practices on Growth and Yield of Sweet Corn (Zea mays L. saccharata)
}

\author{
Bajeetunnisa*, Rajesh Singh and Ekta Singh \\ Department of Agronomy, Sam Higginbottom University of Agriculture, Technology and \\ Sciences, Prayagraj, Uttar Pradesh, India \\ *Corresponding author
}

\section{A B S T R A C T}

\begin{tabular}{l} 
K e y w o r d s \\
Sweet corn, \\
Rabi, Atrazine, \\
Tembotrione, Weed \\
control efficiency, \\
Weed index, \\
Weed density, \\
Weed dry weight, \\
Row-spacing \\
$\begin{array}{l}\text { Article Info } \\
\text { Accepted: } \\
\text { 28 November } 2020 \\
\text { Available Online: } \\
10 \text { December } 2020\end{array}$ \\
\hline
\end{tabular}

\section{Introduction}

Sweet corn (Zea mays corn var. sacharata) is a variety of maize with high sugar content. Sweet corn is gradually becoming an important vegetable crop in India, as it forms a useful ingredient in the preparation of salad and other food ingredient both at home and in hotels. Sweet corn is one type of maize and contains 13 to $15 \%$ sugar in immature grains. Among agronomic practices, which affect the
The experiment was conducted during the Rabi season 2019 at Prayagraj to study the Effect of row-spacing and weed management practices on growth and yield of Sweet corn (Zea mays L. saccharata). The experiment comprised of 2 factors and 10 treatments viz. Row spacings $(40 \mathrm{~cm}$ and $50 \mathrm{~cm}$ ) and weed management practices (Weedy check, Weed free check, Atrazine a.i @ 1.0 kg/ha PRE fb Hand weeding at 20 DAS, Tembotrione a.i @ $120 \mathrm{~g} / \mathrm{ha}$ PoE and Atrazine a.i @ 1.0 kg/ha PRE fb Tembotrione a.i @ $120 \mathrm{~g} / \mathrm{ha}$ PoE. Results revealed that application of $50 \mathrm{~cm}+$ Weed free check gave maximum plant height $(158.6 \mathrm{~cm})$, no. of leaves per plant (12.7), no. of cobs/plant (1.28), no. of grains/cob (819.67). Whereas the maximum dry weight of plant $(212.55 \mathrm{~g} / \mathrm{plant})$, green cob yield $(10.51 \mathrm{t} / \mathrm{ha})$ were obtained with the application of $40 \mathrm{~cm}+$ Weed free check. Stover yield (21.33 t/ha) was maximum with the application of $40 \mathrm{~cm}+$ Atrazine a.i. @ $1.0 \mathrm{~kg} / \mathrm{ha}$ PRE followed by hand weeding at 20 DAS. Lowest weed density, lowest Weed dry weight and highest Weed control efficiency were observed with $40 \mathrm{~cm}+$ Weed free check $\left(1.72 / \mathrm{m}^{2}\right.$, $1.64 \mathrm{~g} / \mathrm{m}^{2}$ and $98.63 \%$ ) followed by Atrazine a.i. @ $1.0 \mathrm{~kg} / \mathrm{ha}$ PRE + Tembotrione a.i. @ $120 \mathrm{~g} / \mathrm{ha} \mathrm{PoE}\left(4.03 / \mathrm{m}^{2}, 3.72 \mathrm{~g} / \mathrm{m}^{2}\right.$ and $\left.91.63 \%\right)$ and Atrazine a.i. @ $1.0 \mathrm{~kg} / \mathrm{ha} \mathrm{PRE}$ followed by Hand weeding at 20 DAS $\left(4.24 / \mathrm{m}^{2}, 5.27 \mathrm{~g} / \mathrm{m}^{2}\right.$ and $\left.85.12 \%\right)$. Whereas lowest Weed index was observed with $40 \mathrm{~cm}+$ Weed free check ( $0 \%$ ), followed by $40 \mathrm{~cm}+$ Atrazine a.i. @ $1.0 \mathrm{~kg} / \mathrm{ha}$ PRE followed by Hand weeding at 20 DAS $(3.50 \%)$ and Atrazine a.i@1.0 kg/ha PRE+Tembotrione a.i @ 120 g/ha PoE (10.15 \%). 
too wide spacing may result in excessive vegetative growth of plant and abundant weed population due to more feeding area available. Optimum spacing allows for easy of field operations and minimizes competition among plants for light, water, and nutrients. Narrow rows make more efficient use of available light and also shade the surface soil more completely during the early part of the season while the soil is still moist.

Although maize (Zea mays L.) plant is vigorous and tall growing in nature, yet it is very sensitive to weed competition at early stages of growth (Mabasa et al., 1996; Kumar and Sundari, 2002). The commonly reported losses due to weeds in maize are greater than 30\% (Rehman, 1985). Uncontrolled weeds may reduce maize yield as much as $90 \%$ (Madrid and Vega, 1976). Weed management can be formulated to minimize the losses due to weeds by means of integrated approach strategy. Manual weeding alone is not sufficient to ensure adequate weed control in maize field. It should be supplemented with chemical or herbicide for effective weed control. Use of Pre-emergence and postemergence application of herbicides would make herbicidal weed control more acceptable to farmers which will not change the existing agronomic practices but will allow for complete control of weeds. Usage of Pre-emergence herbicides assumes greater importance in the view of their effectiveness from initial stages.

Pre-emergence herbicides ensure significant promising weed control and save crop from initial weed competition and nutrient drain. Similarly, the post emergence herbicide also has a significant role in reducing the crop weed competition at the time of critical growth stages of the crop. As the weeds interfere during the harvesting of the crop, post-emergence herbicides at about 40-45 DAS may help in avoiding the problem of weeds at later stages.

\section{Materials and Methods}

The experiment was conducted during the Rabi season of 2019 at Crop Research Farm, Department of Agronomy, Naini Agricultural Institute, Sam Higginbottom University of Agriculture, Technology \& Sciences, Prayagraj (U.P.) India. Soil was sandy clay loam having $\mathrm{pH} 7.2$, organic carbon around $0.42 \%$, available nitrogen at $245 \mathrm{~kg} \mathrm{ha}^{-1}$, available $\mathrm{P}_{2} \mathrm{O}_{5}$ at $14.8 \mathrm{~kg} \mathrm{ha}^{-1}$ and $\mathrm{K}_{2} \mathrm{O}$ at $343.2 \mathrm{~kg} \mathrm{ha}^{-1}$. The experiment was laid out in Randomized Block Design consisting of 10 treatment combinations each replicated three times. Different Row spacings I.e. $40 \mathrm{~cm}\left(\mathrm{~S}_{1}\right)$ and $50 \mathrm{~cm}\left(\mathrm{~S}_{2}\right)$ and Weed Management Practices (Weedy check $\left(\mathrm{W}_{1}\right)$, Weed free check $\left(\mathrm{W}_{2}\right)$, Atrazine a.i @ $1.0 \mathrm{~kg} / \mathrm{ha}$ PRE fb Hand weeding at $20 \mathrm{DAS}\left(\mathrm{W}_{3}\right)$, Tembotrione a.i@120 g/ha PoE $\left(\mathrm{W}_{4}\right)$ and Atrazine a.i @ 1.0 kg/ha PRE fb Tembotrione a.i @ 120 g/ha PoE $\left(\mathrm{W}_{5}\right)$. Treatments were randomly arranged in each replication. Sugar-75 was sown at $20 \mathrm{~cm}$ plant spacing and row spacing as per the treatment.

Recommended doses of nitrogen, phosphorous and potassium were applied. The weeds collected from two randomly selected quadrates $(0.5 \mathrm{~m} \times 0.5 \mathrm{~m})$ were used to estimate the dry matter of weeds. Observations were recorded at 20, 40, 60, 80, 100 , at harvest. Pre-emergence annlication of herbicides was done one $\mathrm{d}(\mathrm{x}+1)$ sowing while post-emergence herbicide was applied at 20 days after sowing. Total weed density was transformed using square root transformation $\sqrt{(\mathrm{x}+1}$ for the statistical analysis. All the data were analyzed statistically by Fisher's least significant difference method at 5\% level of significance using IBM SPSS 24.0 software package developed by IBM Crop. (2016). Data on different growth parameters, yield attributes and yield were recorded from randomly selected ten tagged plants from net plot. 


\section{Results and Discussion}

\section{Growth parameters}

\section{Plant height}

At Harvest, maximum plant height was obtained with the application of $50 \mathrm{~cm}+$ Weed free check $(158.6 \mathrm{~cm})$, which was statistically at par with $50 \mathrm{~cm}+$ Atrazine a.i (a $1.0 \mathrm{~kg} / \mathrm{ha}$ PRE followed by Hand weeding at 20 DAS $(157.96 \mathrm{~cm})$. Significantly higher plant height in lower density (wider spacing) might be due to greater light interception, efficient utilization of soil moisture under lower degree of inter-plant competition. These results are in conformity with observation of Thakur et al., (1991) and Gollar and Patil (2000). Significantly higher plant height in weed free check might be due to better availability of moisture, nutrient, light and space to the crop owing to less weeds in this treatment. These results are in conformity with observation of Thakur et al., (1991) and Gollar and Patil (2000). The lowest plant height in weedy check might be due to more competition between crop and weed for moisture nutrient, light and space. These results are in conformity with observation of Kotru et al., (2012) (Table 1).

\section{Plant dry weight}

At harvest, maximum plant dry weight was obtained with the application of $40 \mathrm{~cm}+$ Weed free check (212.55 g/plant), which was statistically at par with $50 \mathrm{~cm}+$ Weed free check (210.09 g/plant) and $50 \mathrm{~cm}+$ Atrazine a.i @ $1.0 \mathrm{~kg} / \mathrm{ha}$ PRE followed by Hand weeding at 20 DAS (209.66 g/plant) reducing plant population might be due to increase in plant growth, ultimately lead to production of more photosynthates. These results are in conformity with the results of Thakur et al., (1991) and Gollar and Patil (2000). Increase in plant dry weight might be due to better availability of moisture, nutrient, light and space to the crop owing to less weeds in this treatment. These results are in conformity with observation of Thakur et al., (1991) and Gollar and Patil (2000).

\section{Yield parameters}

\section{Cobs/plant}

Maximum no. of cobs/plant obtained with the application of $50 \mathrm{~cm}+$ Weed free check $(1.28$ cobs/plant) which was statistically at par with $50 \mathrm{~cm}$ + Atrazine a.i @ $1.0 \mathrm{~kg} / \mathrm{ha}$ PRE followed by hand weeding at 20 DAS (1.26 cobs/plant). Highest no. of cobs/plant with 50 $\mathrm{cm}$ x $20 \mathrm{~cm}$ row spacing might be due to less competition for space, moisture and nutrients which accelerate normal photosynthesis activity owing to more interception of sunlight. These findings are sustained with those reported by Bhatt (2012) and Golada et $a l$., Highest no. of cobs/plant with weed free check might be due to significant reduction in crop weed competition due to effective control of weeds under this treatment reflected in better growth and development of the crop. These results are in close conformity with the findings of Nadiger et al., (2013) and Mathukia et al., (2014).

\section{Green cob yield}

Maximum green cob yield was obtained with the application of $40 \mathrm{~cm}+$ Weed free check (10.51 t/ha) which was significantly superior over rest of the treatments except with $40 \mathrm{~cm} \mathrm{x}$ 20cm + Atrazine a.i @ 1 kg/ha PRE + Hand weeding at 20 DAS (10.48 t/ha) which was statistically at par with40 $\mathrm{cm}+$ Weed free check. Higher the crop spacing higher the crop population utilized the production resources more efficiently towards plant development. These findings are in agreement with those of Kar et al., (2006). Higher green cob yield with weed free check might be due 
to significant reduction in crop weed competition due to effective control of weeds under this treatment reflected in better growth and development of the crop. These results are in close conformity with the findings of Nadiger et al., (2013) and Mathukia et al., (2014).

\section{Stover yield}

Maximum stover yield obtained with the application of $40 \mathrm{~cm} \times 20 \mathrm{~cm}+$ Atrazine a.i @ $1 \mathrm{~kg} / \mathrm{ha}$ PRE + Hand weeding at 20 DAS (21.33 t/ha) which was significantly superior over rest of the treatments except with $40 \mathrm{~cm}$ + Weed free check $(21.25 \mathrm{t} / \mathrm{ha})$ which was statistically at par with $40 \mathrm{~cm}$ x $20 \mathrm{~cm}+$ Atrazine a.i @ $1 \mathrm{~kg} / \mathrm{ha}$ PRE + Hand weeding at 20 DAS. The remarkable increase in stover yield under $40 \mathrm{~cm}+$ weed free was mainly due to increased plant population these results are in accordance with those of Thakur et al,
(1991) Sukanya et al., (2000) and Bhatt (2012).

\section{Weed studies}

\section{Weed density}

At harvest, the lowest weed density $\left(2.46 / \mathrm{m}^{2}\right)$ was observed in treatment $40 \mathrm{~cm}+$ weed free check followed by $50 \mathrm{~cm}+$ Weed free check $\left(3.04 / \mathrm{m}^{2}\right)$. Besides, weed free check the lowest weed density was followed by $40 \mathrm{~cm}+$ Atrazine a.i @ $1.0 \mathrm{~kg} / \mathrm{ha}$ PRE fb Tembotrione a.i @ $120 \mathrm{~g} / \mathrm{ha} \operatorname{PoE}\left(15.78 / \mathrm{m}^{2}\right)$. The highest weed density resulted in weedy check due to high weed crop competition for nutrients, space, sunlight, carbon dioxide and water which hampered crop growth that resulted in low yield. Similar results were reported by (Sreenivas and Satyanarayana, 1996) and (Mundra et al., 2002) (Table 2).

Table.1 Effect of row-spacing and weed management practices on growth and yield of Sweet corn

\begin{tabular}{|c|c|c|c|c|c|}
\hline Treatment combinations & $\begin{array}{c}\text { Plant } \\
\text { Height } \\
(\mathrm{cm})\end{array}$ & $\begin{array}{c}\text { Dry } \\
\text { weight } \\
\text { (g/plant) }\end{array}$ & $\begin{array}{l}\text { No. of } \\
\text { cobs/plant }\end{array}$ & $\begin{array}{l}\text { Green cob } \\
\text { yield (t/ha) }\end{array}$ & $\begin{array}{c}\text { Stover } \\
\text { Yield (t/ha) }\end{array}$ \\
\hline $40 \mathrm{~cm} \times 20 \mathrm{~cm}+$ Weedy check & 134.33 & 182.51 & 1.05 & 7.85 & 17.23 \\
\hline $40 \mathrm{~cm} \times 20 \mathrm{~cm}+$ Weed free check & 157.03 & 212.55 & 1.15 & 10.51 & 21.25 \\
\hline $\begin{array}{l}40 \mathrm{~cm} \times 20 \mathrm{~cm}+\text { Atrazine a.i @ } 1 \mathrm{~kg} / \mathrm{ha} \text { fb Hand weeding at } 20 \\
\text { DAS }\end{array}$ & 149.2 & 203.35 & 1.16 & 10.48 & 21.33 \\
\hline $40 \mathrm{~cm} \times 20 \mathrm{~cm}+$ Tembotrione a.i @ $120 \mathrm{~g} / \mathrm{ha}$ at 20DAS & 136.66 & 184.21 & 1.09 & 9.39 & 18.42 \\
\hline $\begin{array}{l}40 \mathrm{~cm} \times 20 \mathrm{~cm}+\text { Atrazine a.i @ } 1 \mathrm{Kg} / \mathrm{ha} \text { fb Tembotrione a.i @ } \\
120 \mathrm{~g} / \mathrm{ha}\end{array}$ & 141.93 & 198.62 & 1.09 & 9.49 & 19.86 \\
\hline $50 \mathrm{~cm} \times 20 \mathrm{~cm}+$ Weedy check & 135.63 & 183.23 & 1.16 & 6.72 & 14.65 \\
\hline $50 \mathrm{~cm} \times 20 \mathrm{~cm}+$ Weed free check & 158.6 & 210.09 & 1.28 & 9.93 & 16.80 \\
\hline $\begin{array}{l}50 \mathrm{~cm} \text { x } 20 \mathrm{~cm}+\text { Atrazine a.i @ } 1 \mathrm{~kg} / \mathrm{ha} \text { fb Hand weeding at } \\
20 \text { DAS }\end{array}$ & 157.96 & 209.66 & 1.26 & 8.94 & 16.77 \\
\hline $50 \mathrm{~cm} \times 20 \mathrm{~cm}+$ Tembotrione a.i @ $120 \mathrm{~g} / \mathrm{ha}$ at 20DAS & 156.6 & 208.42 & 1.16 & 8.20 & 16.67 \\
\hline $\begin{array}{l}\text { 50cm x20cm + Atrazine a.i @ } 1 \text { Kg/ha fb Tembotrione a.i @ } \\
\text { 120g/ha }\end{array}$ & 156.63 & 208.49 & 1.25 & 8.91 & 16.67 \\
\hline SEm \pm & 0.74 & 2.10 & 0.018 & 0.13 & 0.21 \\
\hline $\mathrm{CD}(\mathrm{P}=0.05)$ & 2.2 & 6.25 & 0.05 & 0.39 & 0.64 \\
\hline
\end{tabular}


Table.2 Effect of row-spacing and weed management practices on weed studies of Sweet corn

\begin{tabular}{|c|c|c|c|c|}
\hline Treatment combinations & $\begin{array}{c}\text { Weed } \\
\text { Density }\left(/ \mathbf{m}^{2}\right)\end{array}$ & $\begin{array}{l}\text { Weed Dry } \\
\text { weight } \\
\left(\mathrm{g} / \mathrm{m}^{2}\right)\end{array}$ & $\begin{array}{c}\text { Weed } \\
\text { Control } \\
\text { Efficiency } \\
(\%)\end{array}$ & $\begin{array}{c}\text { Weed } \\
\text { Index }(\%)\end{array}$ \\
\hline $40 \mathrm{~cm} \times 20 \mathrm{~cm}+$ Weedy check & $11.18(124.59)$ & 161.60 & 0 & 24.46 \\
\hline $40 \mathrm{~cm} \times 20 \mathrm{~cm}+$ Weed free check & $1.72(2.46)$ & 2.20 & 98.63 & 0 \\
\hline $40 \mathrm{~cm} \times 20 \mathrm{~cm}+$ Atrazine a.i @ $1 \mathrm{~kg} / \mathrm{ha} \mathrm{fb}$ Hand weeding at 20 DAS & $4.24(17.53)$ & 27.29 & 85.12 & 3.50 \\
\hline $40 \mathrm{~cm}$ x20cm + Tembotrione a.i @ $120 \mathrm{~g} / \mathrm{ha}$ at 20DAS & $5.20(26.58)$ & 36.38 & 77.47 & 12.06 \\
\hline 40cm x20cm + Atrazine a.i @ 1 Kg/ha fb Tembotrione a.i @ 120 g/ha & $4.03(15.78)$ & 13.36 & 91.63 & 11.16 \\
\hline $50 \mathrm{~cm} \times 20 \mathrm{~cm}+$ Weedy check & $11.36(128.6)$ & 166.10 & 0 & 32.28 \\
\hline $50 \mathrm{~cm} \times 20 \mathrm{~cm}+$ Weed free check & $1.88(3.04)$ & 2.50 & 98.49 & 0 \\
\hline $50 \mathrm{~cm}$ x $20 \mathrm{~cm}+$ Atrazine a.i @ $1 \mathrm{~kg} / \mathrm{ha}$ fb Hand weeding at 20 DAS & $4.32(18.23)$ & 31.81 & 80.84 & 10.00 \\
\hline $50 \mathrm{~cm} \times 20 \mathrm{~cm}+$ Tembotrione a.i @ $120 \mathrm{~g} / \mathrm{ha}$ at 20DAS & $5.49(29.66)$ & 39.64 & 76.12 & 19.02 \\
\hline 50cm x20cm + Atrazine a.i @ 1 Kg/ha fb Tembotrione a.i @ 120g/ha & $4.09(16.24)$ & 16.57 & 90.01 & 10.15 \\
\hline SEm \pm & 0.22 & 1.82 & 0.21 & 1.09 \\
\hline $\mathrm{CD}(\mathrm{P}=0.05)$ & 0.67 & 5.43 & 0.64 & 3.24 \\
\hline
\end{tabular}

Note: Figure in paranthesis are original values

\section{Weed dry weight}

At Harvest, the lowest weed dry weight $\left(2.20 / \mathrm{m}^{2}\right)$ was observed in treatment $40 \mathrm{~cm}+$ weed free check followed by $50 \mathrm{~cm}+$ Weed free check $\left(2.50 / \mathrm{m}^{2}\right)$. Besides, weed free check the lowest weed density was followed by $40 \mathrm{~cm}$ + Atrazine a.i @ $1.0 \mathrm{~kg} / \mathrm{ha}$ PRE fb Tembotrione a.i @ $120 \mathrm{~g} / \mathrm{ha} \operatorname{PoE}\left(13.36 / \mathrm{m}^{2}\right)$. The minimum weed dry weight, might be due to effective control of weeds. In addition to this, dense crop canopy might have suppressed weed growth and ultimately less biomass. The weedy check recorded significantly highest weed dry weight owing to uncontrolled condition favored luxurious weed growth. These findings are in close conformity with those reported by Sinha et al., (2003), Kolage et al., (2004) and Verma et al., (2009).

\section{Weed control efficiency}

At harvest, maximum weed control efficiency (98.63\%) was observed in $40 \mathrm{~cm}+$ weed free check and $50 \mathrm{~cm}+$ weed free check $(98.49 \%)$. Besides weed free check maximum weed control efficiency (95.63\%) observed in 40 $\mathrm{cm}+$ Atrazine a.i@1.0 kg/ha PRE fb Tembotrione a.i@120 g/ha PoE and $50 \mathrm{~cm}+$ Atrazine a.i @1.0 kg/ha PRE fb Tembotrione a.i @ $120 \mathrm{~g} / \mathrm{ha}$ PoE (90.01\%). However, lowest weed control efficiency (76.12\%) observed in $50 \mathrm{~cm}+$ Tembotrione a.i @ 120 $\mathrm{g} / \mathrm{ha}$ PoE. The maximum weed control efficiency, might be due to effective control weeds under. In addition to this, dense crop canopy might have suppressed weed growth and ultimately less biomass. The weedy check recorded significantly lowest control efficiency owing to uncontrolled condition favored luxurious weed growth. These findings are in close conformity with those reported by Sinha et al., (2003), Kolage et al., (2004) and Verma et al., (2009).

\section{Weed index}

At harvest, lowest weed index $(3.50 \%)$ observed in $40 \mathrm{~cm}+$ Atrazine a.i @ $1.0 \mathrm{~kg} / \mathrm{ha}$ PRE fb Hand weeding at 20 DAS. However, highest weed index (32.28\%) $40 \mathrm{~cm}+$ Weedy check. The minimum weed index in weed free and $40 \mathrm{~cm}$ + Atrazine a.i @ $1.0 \mathrm{~kg} / \mathrm{ha}$ PRE fb 
Hand weeding at 20 DAS might be due to effective control weeds under these treatments. In addition to this, dense crop canopy might have suppressed weed growth and ultimately less biomass. The weedy check recorded significantly highest weed index owing to uncontrolled condition favored luxurious weed growth. These findings are in close conformity with those reported by Sinha et al., (2003), Kolage et al., (2004) and Verma et al., (2009).

Based on experimental findings it may be concluded that besides weed free check, lowest weed density and weed control efficiency were observed with the application of $40 \mathrm{~cm}$ + Atrazine a.i @ $1 \mathrm{Kg} / \mathrm{ha}$ PRE fb Tembotrione $120 \mathrm{~g} / \mathrm{ha}$ PoE and highest green cob yield was maximum with the application of $40 \mathrm{~cm}$ + Atrazine a.i @ $1 \mathrm{~kg} / \mathrm{ha}$ PRE fb Hand weeding at 20 DAS. Since these findings are based on research done in one season under agro - ecological conditions of Allahabad it may be repeated for confirmation.

\section{References}

Bhatt, P. S., Response of sweetcorn hybrid to varying plant densities and nitrogen levels. African Journal of Agricultural Research, 7(46): 6158-6166 (2012).

Davi, C.M., B.R. Reddy, P.M Reddy and S.C.S. Reddy. 1995. Effects on Nitrogen levels and plant density on yield and quality of JKHY-1 cotton. Curr. Agri. Res., 8(3/4): 144-146. (Field Crop Abst., 49(11): 8267; 1996).

Golada, S. L., Sharma, G. L. and Jain, H. K., Performance of baby corn (Zea mays L.) as influenced by spacing, nitrogen fertilization and plant growth regulators under sub humid condition in Rajasthan, India. African Journal of Agricultural Research, 8(12): 1100-1107 (2013).

Gollar, R. G. and Patil, V. C., Effect of plant density on growth and yield of maize genotypes during rabi season. Karnataka Journal of Agricultural Science, 13(1): 1-6 (2000).

Kar, P.P., Barik, K.C., Mahapatra, P.K., Garnayak, I.M., Rath, B.S., Bastia, D.K. and Handa, K. 2006. Effect of planting geometry and nitrogen on yield, economics and nitrogen uptake of sweet corn (Zea mays). Indian Journal of Agronomy. 51: 43 - 45.

Kolage AK, Shinde SH, Bhilare RL (2004) Weed management in kharif maize, Journal of Maharashtra Agricultural Universities, 29: 110-111.

Kotru, R., Singh, L., Singh, P., Qayoom, S. and Singh, K. N., Growth and yield of baby corn (Zea mays L.) as influenced by sowing dates and weed management practices under temperate conditions. Haryana Journal of Agronomy, 28(1\&2): 11-18 (2012).

Kumar, S.M.S and A. Sundari. 2002. Studies on the effect of major nutrients and crop-weed competition period in maize. Indian J. Weed Sci., 34(3-4): 309-310.

Lawson, H.M and P.B. Topham. 1985. Competition between annual weeds and vining peas grown at a range of population densities: effects on the weeds. Weed Res., 25: 221-229.

Mabasa, S., A.M Rambakudzibga, O. Ndebele and F. Bwakaya. 1995. A survey of maize production practices in three communal areas of Zimbabwe. Paper presented at the Rockefeller Soil Fertility Network Meeting, 17-21 July 1995 Kadoma, Zimbabwe.

Madrid, M.T and M.R. Vega. 1976. Duration of weed control and weed competition and the effect on yield of maize (Zea mays). Philippine Agric., 55: 216-220.

Malik, V.S., C.J. Swanton and T.E. Michaels.1993. Interaction of white bean (Phaseolus vulgaris) cultivars, row spacing and seeding density with annual 
weeds. Weed Science, 41: 62-68.

Mathukia, R.K., Choudhary, R.P., Shivran, A. and Bhosale, N. 2014. Response of rabi sweet corn to plant geometry and fertilizer. J. Crop Weed, 10:189-92.

Mundra, S.L., Vyas, A.K. and Maliwal, P.L. 2002. Effect of weed and nutrient management on nutrient uptake by maize (Zea mays) and weeds. Indian Journal of Agronomy. 47(3): 378- 383.

Nadiger, S., Babu, R. and Kumar, B.N.A. (2013). Bioefficacy of pre-emergence herbicides on weed management in maize. Karnataka J. Agric. Sci. 26: 1719.

Rehman, A. 1985. Weed control in maize in New Zealand. Pp 37-45 In: MaizeManagement to Market. (Eds.): H.A. Eagles and G.S. Wratt. Agron. Soc. N.Z., Special pub. No. 4, Palmerston North, New Zealand.

Sinha SP, Prasad SM, Singh SJ, Sinha KK (2003) Integrated weed management in winter maize (Zea mays) in North Bihar. Indian Journal of Weed Science, 35:273-274.

Sreenivas, G. and Satynarayana, V. 1996. Nutrient removal by weed and maize (Zea mays). Indian Journal of Agronomy, 41(1): 160-162.

Sukanya, T. S., Najnappa, H. V. and Ramchandrappa, B. K. 2000. Effect of spacings on the growth, development and yield of baby corn varieties. Karnataka J. Agricultural Sciences. 12(1-4): 10-14.

Thakur, D. R and V. V. Malhotra, 1991. Response of popcorn to row spacing and nitrogen, Indian J. Agric. Sci., 61: 586-587.

Verma VK, Tewari AN, Dhemri S (2009) Effect of atrazine on weed management in winter maize-green gram cropping system in central plain zone of Uttar Pradesh. Indian Journal of Weed Science, 41: 41-45.

\section{How to cite this article:}

Bajeetunnisa, Rajesh Singh and Ekta Singh. 2020. Effect of Row-spacing and Weed Management Practices on Growth and Yield of Sweet Corn (Zea mays L. saccharata). Int.J.Curr.Microbiol.App.Sci. 9(12): 3403-3409. doi: https://doi.org/10.20546/ijcmas.2020.912.404 